\title{
ENTREPRENEURSHIP IN VISUAL ARTS
}

\author{
Okogwu Antonia \\ Department of Fine Arts and Design \\ University of Port Harcourt \\ DOI: 10.31364/SCIRJ/v6.i12.2018.P1218595 \\ http://dx.doi.org/10.31364/SCIRJ/v6.i12.2018.P1218595
}

\begin{abstract}
Visual Arts Education System is based on practical studio oriented studies that are less lettered but highly academic and pragmatic practices, tailored to suit the direct needs of the society. This is contrary to the idealistic educational conventions pervading Nigeria educational system. Visual Art Educational Scheme of study perhaps holds the key as an alternative to the education system that is self-reliant and self-sustaining as opposed to the numerous heavily lettered educational schemes that have rendered many graduates unemployed in a growing economy with fast growing population. Visual Art Education System specializes in practical studio training in various fields of endeavour: Sculpture, Painting, Ceramics, Textiles, Graphics and of course the theoretical ones as Art Education, Art History and Art Administration .The training of a Studio Artist is such that he is self-reliant and self-employed and as such is very different from the common educational schemes that are geared towards making students heavily dependent on white collar jobs that are few or none at all in Nigerian economy of today, thereby making them handicapped in this present dispensation.There is something to learn in the studio system of education so as to redesign other courses within the tertiary institutions in order to lessen the pressure on unemployment in the Country.
\end{abstract}

Keywords: Art, Entrepreneur, Business, Reprogramming, Studio Practice.

\section{Introduction}

Talent or artistry that cannot be harnessed to its optimum and for the benefit of mankind is a waste especially in developing country like Nigeria. There are some courses that are mounted by the Nigerian Universities which are luxury to a developing economy just as the futuristic Vision 20-20-20 programme of the Federal Republic of Nigeria has evolved a heavy financial weight on the encumbered situation of Nigeria economy. It is not enough to chum out graduates from tertiary institutions without interactions with the economy to know the areas that manpower is needed. A lot of focus is on the white collar job but how many of the graduates can be employed by the government? How many vacancies exist in the three tiers of government in Nigeria in relation to the number of those looking for employment? It is high time we redressed, repackaged, reprogrammed and also rebranded courses within the tertiary institutions to be geared towards self-employment, taking into cognisance the needs within the society.

In this period of unemployment of numerous youths who are graduates searching for unavailable white collar jobs in the Nigeria labour market, the Visual Arts Education Scheme is key to this monstrous problem in Nigeria .The orientation in training and scholarship in the Arts and Design discipline is such that encourages less lettered academic studies geared towards pragmatic practical practices that directly satisfy the needs of the society and so are viable and sustainable. There are various areas of industry within Fine Arts and Design, and they are Sculpture, Painting, Ceramics, Graphics, Textile and the highly theoretical Art History, Art Education and Art Administration. It is only in few courses and essentially in Fine Arts and Design that students start specializing even in their first degree level and are professionals in their various fields. In the areas of Design which are Ceramics, Graphics and Textiles there are various cottage industries and other entrepreneurial ventures that can be sourced from this sphere of study.

Ceramics is essentially baked clay and it is also centred on clay and it's enhancement for the use of humanity. Ceramics or what the typical British calls Pottery has several areas such as Sanitary wares, Ornamental wares, Dinner wares, Auto parts, Souvenirs/Decorative wares, Fashions/Jewelries wares and the widest spectrum Architectural wares These areas are utilitarian wares that are in high demand in Nigeria. Under the Sanitary wares are toilet seats and shanks, wash hand basins and bath tubs .All these sanitary wares are needed in new homes as well as old homes especially in terms of replacements. For one to specialize in this area one needs enough quantity of clay deposit and high firing Kiln. However this is capital intensive even though it is 
lucrative.

Another area is the Ornamental wares that include flower vases, Ceramic Sculpture, and plaques. In this area one does not need high temperature firing Kiln and it is highly viable especially if the prices are dropped and are mass produced that they become affordable considering the Nigerian economy and the income and wages .In this area, it is recommended for those with small capital because it is not labour intensive and the machines required are Kiln, Throwing Wheels, Plunger and Purge mill. Clay which is the main consumable material is in abundance in Nigeria. One must not fail to highlight the problem of electricity in the country so as to make adequate provisions for alternative energy supply.

The area that parades the widest spectrum of wares is in the sphere of Ceramic- architecture includes, Bricks, Roofing Tiles, Pillar Pots, Interlocking Paving Bricks, Sewage Pipes, Conduit Pipes and Electric Insulators. These are industrial products that are also in high demand especially in our developing country, Nigeria. Auto ware is the ceramic part found in auto spark plugs, it acts as insulator for the fireworks that go on in vehicles. The nature of fired Clay is such that it is poor in conductivity and can withstand very high temperature. Its production is highly technical requiring expertise and accurate tensile calculations.

Fashion/Jewelries/Accessories are a big industry anywhere in the world. Nigeria has a large market and ceramic beads featured uniquely in the just concluded $1^{\text {st }}$ African Art and Craft Expo in Abuja. This is one area that people should cash in on as there is a great demand on beads currently in Nigerian market in the Fashion sector. Souvenirs/Decorative ware houses ceramic Plaques, Planters, Flower Vases, one such aspect of Ceramics is an area called Dinner Wares, Porcelain Wares, and Soft Stone. These Wares serve direct utility function in homes and eateries.

Still within the Design sector is one area that cannot be ignored, the Graphics Galaxy that touches every aspect of life. Book Making, Illustration of Books, Publication Design, Seasonal Design, Image Design, Security Design, Photo Documentation, Photo Graphics, Photography, Cyber Art, Environmental Communication, Print Making, the list is endless. One thing that must be noted in Graphics is, one can start a simple business with very little capital and still make it. In Book Making sector, the author is expected to hand over his manuscript to the Graphic Designer to design and typeset the pages and also do the illustrations as well as the cover pages. This area is not very viable in Nigerian market due to the fact that the issue of writing books is done by few people especially within the Universities. Most often, the Publishing houses employ the Graphic artists. Publication Design, another aspect of Graphic Design, houses Magazines, Catalogues, Annual Reports, Bulletins, Newspapers, Journals and Encyclopedias. This area is money spinning and very lucrative even as little as printing of ordinary office files and production of Exercise Books. Package Design consists of design that is for packaging products, enhancing its aesthetic appeal to the consumers and it includes Cosmetics, Pharmaceuticals, Tobacco, Video, Cassettes, Food and Drinks.

Seasonal Design is another area of the Graphics Galaxy that carters for all seasonal cards such as Christmas Cards, Birthday Cards, Calendars and Dairies. Some Designers actually make a living on this aspect of Graphics. It is viable and sustainable, especially when one is highly talented and combines this with Image Design. The image design entails designing for Corporate Identity Programme, Logo, Letter Heads, Call Cards, Advertising Design, Promotional Design and Publicity Design. Security Design is a sensitive one that requires some sort of license to go into Paper Money, Certificates, Bill of Quantity, Seals and Stamps. Photo graphics and Photography are areas that thrive even within the medium or micro economic sector in Nigeria.

Environmental Communication is another area that the Photography aspect of Graphics plays a major role as Cameras are mounted to watch the environment. Spy Photography is also employed to keep track of natural and manmade phenomenon. Cyber Art and Design is the latest entrant in the Graphics Galaxy and is hot in the Nigerian market where websites are designed and more of the cybernetics are patronised. Printing is another area that is viable even with the small printing machine, a good location, a Printer and a serious entrepreneur who can turn things around. Sustainability in any business venture must take into consideration the entrepreneur's interest, the location of the business and the capital.

Textile is another area within the Design ambit of Applied Arts that is highly viable in Nigerian economy. It is an area that 
concerns itself with the business of cloth and clothing right from fibre to finished fashion The Nigerian market is so receptive to fashions and does appear that every sector of the economic strata in Nigeria is interested in this area. One will quickly ask some silent questions as why the Textile Mills in Nigeria are closing down and I dare to say that this area is viable. What happened to Nigeria Textile Mills is lack of vision in terms of policy and managerial dispositions. The Abeokuta Adire ventures which are private indigenous textile ventures are positive test cases in the Nigerian fabrics industry .It does not only sell in Nigeria alone that has a very large market but also outside the country. Adire fabrics are not just used for male and female garments alone they are also used for interior furnishing, beddings and quilts.

Another area that is worth researching in Textile is the area of tapestry, this is necessary because the Persian rugs are banned in Nigeria. Local rugs with African motifs and designs are taking over the Persian ones as well as serve as gift items for the tourism Industry in Nigeria. Fashion business or Industry is a large one in Nigeria and the whole world at large that cannot be ignored. One area that needs more attention is the area of men's wears. Innovative ethnic wears turned into contemporary wears can thrive in the cycle of politicians that really control money in Nigeria. A centre for training people in this Textile Art is also viable in the city centres for many people who would like to empower themselves, there are workshops and conferences all centred on textile and fashions.

Painting is within the Fine Art spectrum of Arts. It is concerned with the aesthetics of colours and under the entrepreneurial endeavour. Mosaic Paintings, Mural Paintings, Stained Glasses and Portraiture are viable. A mosaic artist mainly works on commission bases and the art involves the use of small tiles to make designs on walls especially at strategic places like Airports, Public Places, Churches, and Auditoriums. Once an artist gets this kind of commission from government and it is properly paid for, such artist is made. The Portrait Artist engages in painting individual or group portraits of various sizes and media tailored to the taste of his client. Once the Artist is able to get the true resemblance of his client and the colour rendition is right, he attracts more clients and makes more money. Seascapes, Landscapes and other forms of Paintings are sold in exhibitions and art collectors are ever ready to patronize these exhibitions. In this area the Artist needs a good connection with the upper class of the society. Furthermore the artist with the skill will also require being dogged, resilient, good market drive to sustain the business. The problem with this area is that when once a Painter gets one or two commissions of portraits and he or she is well paid, he goes home to relax until the money finishes instead of striving more to get more commissions.

In the area of Sculpture the numerous materials and methods of production make this sphere of endeavour highly innovative and as such many entrepreneurial ventures can be located here, Funeral Art:- Tombs, Busts and Artistic coffins, Funeral Screens, Monuments, City Sculptures, Artistic Furniture. Architectural Sculptures, Forensic Sculptures, Waste recycled Sculptures, Fashion based Sculptures and Educational Sculptures. Under the Funeral Sculptures one must bear in mind that Nigerians spend a lot of money in burial rites of their beloved ones and a good entrepreneur cashes in on this. The tombs, coffins. Busts and funeral screens are all areas that attract good chunk of money. One man that benefited immensely from this area of venture is the late Chinedu Blessing Oparaocha in Enugu who innovatively went into making the corpse sit in a car as well as sit in the church. In this venture you must be strong and fearless. It is not for the lily levered or for the chicken hearted though it accrues immense money.

City Sculptures, are out door three dimensional works of art that are placed in strategic places within the city or outside the city. They are often commissioned by the government to commemorate some events and to beautify the cities. In Asaba there is one such City Sculpture called Ekumeku war in remembrance of Asaba war with the early Europeans. The Liberty Statue in New York, the Lions in Trafalgar Square in London, Eyo Masquerades in Lagos are all City Sculptures. Artistic Furniture is another lucrative venture within the interiors of Architecture, unique artistic furniture is a toast of many wealthy Nigerians to show off their wealth. Architectural Sculpture consists of Pillars, Plaster of Paris Ceiling, Door Panels, Balustrades, Interlocking Paving Stones and Water Fountains. These types of Sculptures are well patronised within Nigeria.

Forensic Sculpture is a new area that started in University of Port Harcourt between the Department of Fine Arts and Design under Chile Oparaocha, a Sculptor and the Department of Human Anatomy and they came up with first black Anatomical 
Models. Recycled metal waste is the research area of the writer and Kerosene Stoves of durable quality are already in the market and highly appreciated by the public. The waste of metal beds that are no longer in use are sourced with empty discarded gas jars and fabricated into triangular stoves of various sizes. This venture is also lucrative because little money is used to make products that are in high demand.

Fashion based Sculptures are Mannequins and resin cast Beads. These product Sculptures are always in demand for exhibiting Fashion wares in the large fashion market. The cast beads of various sizes and colours are Accessories for the Fashion Industry. The recently concluded Nigeria Fashion Week 2008, Women Affairs from South Africa came out with such unique beads and the patronage was good. In the same vein Jimmy Crystals from New York resurfaced planes with shimmering Crystals of Watches, Glasses, Pens and Cigarette Cases. Educational Sculptures are models used for studies like the human skeleton and other relief Sculptures as demonstrational models and this is an aspect that is lucrative but not yet popular. Many of these entrepreneurial ventures require hard work and dedication with matching passion.

\section{Assessing Loans}

Studies by William F. S. and Webster L. on the World Bank economic review on how small enterprises in Ghana have responded to adjustment indicates that most firms were strained given rise to more competitions for survival. Two broad group of entrepreneurs are identified; the dynamic successful adapters and the stagnant producers. Tolulope 1. Akinbogun studied the impact of Nigerian Business Environment on the survival of small scale Ceramics, in South Western Nigeria within the time frame of post-Independence to this present time. One can source for loans from the family, The Micro finance banks, the various government Agencies- SMEIES-Small and Medium Scale Enterprises Investment Equity Scheme SMEDAN-Small and MediumScale Enterprises Development NDE-National Directorate of Employment and NAPEP-National Poverty Eradication Programme

\section{Case Study of Two Art Enterprises: Getelle Press and Tman Computers.}

Getelle Press Limited is basically a graphic outfit situated at number sixty seven Rumuola road in the business hobnob of Port Harcourt. This business outfit was conceived in 1979 by Nics Ubogu in his undergraduate days in University of Benin and he acknowledges being encouraged by Nduka Ubaegbuna the publisher of THIS DAY newspapers. This entrepreneurial venture started producing designs for prominent companies in Port Harcourt. Acquisition of state of the art digital printing Machines positioned Getelle Press Limited for high class clients. Quality, doggedness, prompt delivery and rational pricing kept this company that is manned by ten personnel and is worth over a hundred million naira going, even in a depressed economy in Nigeria. Some of their products are diaries, calendars, annual reports and company profiles.

Another studied Art Enterprise is Tman Computers situated in the Department of Fine Arts and Design, University of Port Harcourt a successful venture that was started by Truman Icheku who is computer prone graduate who got bored of staying at home and waiting to be given handout by parents. He started Tman Computers with one desktop Computer that he acquired as a student and attached himself to his aunty in a business place within the University of Port Harcourt. This business has grown to about fifteen Computers, five Printers and has employed six workers and the whole outfit is worth Three million naira and spanning four years.

\section{Conclusion}

Many of these entrepreneurial ventures require hard work, perseverance and dedication with matching passion. The various Studio areas in the Visual Arts Studies, Sculpture, Painting, Textiles, Graphics and Ceramics are all spots of entrepreneurial ventures and the Studio teaching method could be utilized in redesigning the tertiary curriculum of education in Nigeria in order to achieve selfsustainability. This studio practice system of education discourages the quest for white collar jobs and this will invariably reduce the pressure on unemployment in Nigeria. 


\section{References}

Freestone, I.G. (Ed) (1997) Pottery in the Making, World Ceramics Traditions, British Museum press.

Kosemani, J. M. (Ed) (2002) Introduction to Education University of Port Harcourt Press, Port Harcourt.

Michael, Cardew (1969) Pioneer Pottery: St. Matin’s Press, Inc.New York Pp237- 254.

Uniport News April-July 2008-10-01.

World Bank (2008), Oxford Journals-Online ISSN 1564-698x-Print ISSN 0258- 6770. 